\title{
Fertilizer Rate and Number of Applications Impact Growth of Trees in Field Soil
}

\author{
Edward F. Gilman and Michael D. Marshall
}

\begin{abstract}
Fertilizer recommendations for producing shade trees in nursery field soil in North America appear to be based on tradition and tree performance; there is little empirical data. This study was designed to examine efficacy of reducing traditional or historical fertilizer amount (rate) and number of applications for two taxa and to present a protocol for growers to test fertilizer use efficiency. A traditional rate of fertilizer was applied along with four others: zero, one-third, two-thirds, or one-and-one-third traditional. Fertilizer was divided into one, two, three (traditional), or four equal amounts applied during the growing season. The study was conducted on a fine sand field soil with 680 trees of each taxa in adjacent plots of the same field. There were 16 factorial treatment combinations plus a non-fertilized control. Fertilizer rate cut to one-third of the historical rate, and number of applications reduced from three to either one or two, resulted in little if any reduction in trunk diameter or height growth over the four-year period. These taxa appeared to grow almost regardless of nitrogen application strategy. Growers can partner with a research team to find an efficient fertilizer rate and number of applications that could cut production costs.

Key Words. Fertilizer; Nursery; Tree Height; Trunk Diameter.
\end{abstract}

The recommended rate for fertilizing shade trees ranges from zero to $29 \mathrm{~g} \mathrm{~N} / \mathrm{m}^{2}$ (Smiley 1998). Rates have also been reported as $\mathrm{g} / \mathrm{cm}$ of trunk diameter (caliper, Struve 2002). According to Rose (1999), these recommendations were based on research that was conducted from the 1950 s to the 1970 s to determine the maximum growth response to fertilizer. Although Rose (1999) reports that these recommendations are higher than rates for agronomic crops, a larger portion of the soil surface in an agronomic field may receive fertilizer. Therefore, the actual amount of fertilizer applied to a nursery field soil may be similar to that of an agronomic field because only a fraction of the nursery field (i.e., the small area around the trunk or a band along the row) receives fertilizer.

Nitrogen is typically applied to the soil surface with the intention of evoking a shoot or root growth response in nursery and landscape trees (Jacobs 1930; Chadwick et al. 1957; Neely et al. 1970; Watson 1994). Schulte and Whitcomb (1975), Hensley et al. (1988), Fini et al. (2007), and others found that nitrogen $(\mathrm{N})$ applied to the soil around young trees at planting resulted in more growth than trees receiving no supplemental $\mathrm{N}$ the first year after planting.
However, there are numerous reports of recently planted young trees not responding to $\mathrm{N}$ applications (Shoup et al. 1981; van de Werken 1981; Whitcomb 1981; Wright and Hale 1983; Khatamian et al. 1984; Ponder et al. 1984; Gilman and Yeager 1990). Despite the apparent consistent fertilizer rates among many of these studies, differing application areas and unclear procedures make true comparisons difficult.

Established trees in a landscape setting have responded to $\mathrm{N}$ applications (Neely et al. 1970; van de Werken 1984) or not responded (Perry and Hickman 1998; Watson 2010). In contrast, trees and shrubs showed a significant response to $\mathrm{N}$ fertilizers when plants were grown in recreated soils (using subsoil material of low fertility) that would be typical of those encountered in urban landscapes by inverting the soil profile during development and construction activities (Rose and Joyner 2003). This may suggest that a lack of response on some test sites may be due to high native fertility (Struve 2002). Watson (1994) determined that root growth increased in response to $\mathrm{N}$ application but Warren (1993) showed it was suppressed at high $\mathrm{N}$ concentrations. Response of nursery and 
landscape trees in field soil appears to be independent of fertilizer formulation (Gilman et al. 2000; Struve 2002; Robbins 2006; Mathers et al. 2012).

Established trees generally have not responded to applications in excess of $14-24 \mathrm{~g} \mathrm{~N} / \mathrm{m}^{2} /$ year (Conover and Joiner 1974; van de Werken 1984; Gilman and Yeager 1990; Ingram et al. 1998; Gilman et al. 2000), although there are isolated examples of increased tree trunk and shoot growth with rates up to $49 \mathrm{~g} \mathrm{~N} / \mathrm{m}^{2} /$ year (Klein et al. 1988). One showed increasing foliage color and flowering with rates up to $72 \mathrm{~g} \mathrm{~N} / \mathrm{m}^{2}$ (Gilman 1987). Fertilizer rates of 2.4-14.4 g N/m²/year were reported as suitable for Japanese holly (Ilex crenata), forsythia (Forsythia sp.), and crapemyrtle (Lagerstroemia sp.) (Rose and Joyner 2003). Cabrera and Devereaux (1999) found that increased $\mathrm{N}$ fertilization during nursery production had a positive effect on post-transplant growth of crapemyrtle. Flowering was delayed in those plants grown under higher $\mathrm{N}$ conditions.

Providing uniform $\mathrm{N}$ recommendations from the literature for shade tree nursery crops is difficult due to differing application areas around the trunk among past studies, differing tree species and tree sizes, and varying soil types, climate, and seasonality of rainfall patterns. This study was designed to determine efficacy of 1) reducing the traditional or historical amount of fertilizer and 2) reducing the number of applications required to grow a quality shade tree crop in a sandy soil. Also presented is a protocol for growers to test fertilizer use efficiency in their operations. The specific objective of the study was to compare growth in a field nursery from five fertilizer rates (including non-fertilized control) of one formulation applied at once or divided into two, three, or four equal applications spread throughout the growing season. The growing season appears to be the most efficient time to apply fertilizer to trees (Rose 1999).

\section{MATERIALS AND METHODS}

\section{Trees, Soil, and Water}

Quercus virginiana Mill. Cathedral $\mathrm{Oak}^{\oplus}$ and Ilex attenuata 'East Palatka' Ashe. (both from cuttings) were planted from 3.7 L containers in November 2004 into an exceptionally well drained fine sand field soil at Marshall Tree Farm in Levy County Florida, U.S. (USDA hardiness zone 8a). Soil pH was
5.20 (water soluble) and 7.65 (buffer) and CEC was $3.9 \mathrm{meq} / 100 \mathrm{~g}$. The field was a cattle pasture without fertilization for many years prior to being converted to a nursery. Trees were $1.8 \mathrm{~m}$ apart within rows of 84 trees; rows alternated 2.4 and $3.6 \mathrm{~m}$ apart. Irrigation was applied through one drip emitter twice daily (11 L daily) during the growing season (March through October), about once daily $(4 \mathrm{~L})$ in the dormant season (November through February) totaling about 3,224 L annually. NOx- $\mathrm{N}$ in water from the well supplying irrigation to this field was measured once on two samples after completion of the study.

Root pruning on Quercus was conducted with a $1.1 \mathrm{~m}$ long, square-tipped hand digging spade with a $36 \mathrm{~cm}$ long blade inserted into soil to its full length at an angle similar to a mechanical digging spade four times in both 2006 and 2007. Two one-eighth circumference arcs were cut opposite one another in May, June, July, and August of the third and fourth years starting $18 \mathrm{~cm}$ from the trunk, moving 1-2 $\mathrm{cm}$ out from the trunk at each subsequent pruning. Thus, the entire circumference of the root system was cut in both years. Root pruning during production is standard practice for Quercus in the region.

Shoots were pruned generally twice annually to develop a dominant central leader in the crown, and trunks on Quercus were gradually cleared by removing branches attached to the lower $1.3 \mathrm{~m}$ of trunk. Ilex branches were sheared twice annually (including the leader) to create the typical, industry-accepted symmetrical cone shape. The small pieces of branch debris were left where they fell; the longest pieces were placed between rows within the plot and mowed with the ground vegetation. Ground vegetation was suppressed in a one meterwide strip within rows with periodic applications of glyphosate; bahiagrass (Paspalum notatum Flueggé) and other vegetation between rows were mowed to approximately $15 \mathrm{~cm}$ height about eight times annually. Tree height and trunk diameter (caliper, using a diameter tape) at $15 \mathrm{~cm}$ from the ground were measured at planting on 50 randomly chosen trees and at the end of the 2005, 2006, 2007, and 2008 growing seasons on all 1360 trees. Increase in tree height and caliper was calculated by subtracting the previous year's value from the current year. The first reported data was growth increase for 2006, which was calculated by subtracting the late 2005 measurements on every tree from data collected late 2006. Growth 
data for the 2005 growing season were not reported because all trees were not measured at planting.

\section{Fertilizer Treatments}

Treatments included a non-fertilized control (zero rate) and 16 combinations of fertilizer amount (reported as rate) and application timing (reported as frequency). Fertilizer was surface-applied to a circular soil area centered on each trunk, using a customized cup appropriately sized for each treatment, beginning March 2005 through August 2008. The traditional or historical annual rate used by the nursery, and generally recommended for field nurseries in that part of Florida, was designated the 1.0 historical rate, which was $284 \mathrm{~g}$ applied around each tree in Year 1 (2005), $908 \mathrm{~g}$ in Year 2, and $1090 \mathrm{~g}$ in Years 3 and 4. The increasing amount is thought to accommodate increase in tree size. Growers typically divide fertilizer into three equal amounts applied about March, May/June, and July/August. This served as the benchmark for comparison. Annual amounts equal to one-third (0.33), two-thirds (0.66), and one-and-one-third (1.33) historical comprised the remaining rates. These four amounts were applied either all at once in May; divided into two equal amounts and applied in both March and June; divided into three equal amounts and applied March, May, and July; or divided into four equal amounts and applied in March, April, June, and August.

The custom blended granular fertilizer (Graco Fertilizer Company, Cairo, Georgia, U.S.) was an $18 \mathrm{~N}, 1.76$ P, $6 \mathrm{~K}$ derived from $49 \%$ water insoluble $\mathrm{N}$ (from sulfur coated urea and activated sewage sludge) and $51 \%$ soluble $\mathrm{N}$ (from ammonium nitrate and diammonium phosphate) equivalent to $51,163,196$, and $196 \mathrm{~g} \mathrm{~N} /$ tree annually for the 1.0 rate for $2005,2006,2007$, and 2008, respectively. The circular area fertilized was $0.65 \mathrm{~m}^{2}$ for all years. The result was a 1.0 historical annual rate of $78,250,302$, and $302 \mathrm{~g} \mathrm{~N} / \mathrm{m}^{2}$ for Years 1, 2, 3, and 4, respectively expressed on an applied area basis. However, only $1.3 \%$ of the field plot surface received fertilizer (i.e., the $0.65 \mathrm{~m}^{2}$ circular area around each trunk); therefore, when expressed on an entire field plot basis, the 1.0 historical rate was $1.0,3.25,3.93$, and $3.93 \mathrm{~g} \mathrm{~N} / \mathrm{m}^{2}$ for Years 1, 2, 3 and 4 , respectively. Another way to report the historical rate is $\mathrm{N}$ applied per unit $(\mathrm{cm})$ caliper for Ilex
(41, 36, and $25 \mathrm{~g} \mathrm{~N} / \mathrm{cm}$ caliper) and for Quercus (35, 29 , and $21 \mathrm{~g} \mathrm{~N} / \mathrm{cm}$ caliper) using caliper measured at the end of 2006, 2007, and 2008, respectively.

\section{Application Procedures}

Signs were installed at the four corners of the test plot stating, "Do not fertilize between signs." Combined with a sign in the middle of the north and south borders, the six signs instructed nursery personnel not to fertilize over the test during normal fertilizations of the nursery. Fertilizer was applied beginning at the southwest corner working northward and down a double row. Each plot of 10 trees was labeled by a vertical wood stake $1.5 \mathrm{~m}$ tall, instructing the farm manager as to the month to apply fertilizer, which scoop to use, and how many of these scoops to apply. Precalibrated customized scoops were of appropriate volumes to deliver the correct fertilizer amount when filled to the rim. Each had a unique label matching that of each stake in the field (e.g., the label "5- 3- A" meant for fertilization in May and the application of three of the 'A' scoops).

\section{Experimental Design and Statistical Analysis}

All trees of one species were placed together in one field; those of the other species began $3.6 \mathrm{~m}$ away in an adjacent field. Species comparisons were not included in the analysis. Trees were in a randomized complete block design with four blocks. Each block contained 17 plots, one for each treatment, containing 10 trees each that received a similar treatment grouped together in two adjacent rows of five trees spaced $1.8 \mathrm{~m}$ apart within rows $\times 2.4$ $\mathrm{m}$ apart between rows. The 17 treatments randomly assigned to plots of 10 trees were four fertilizer rates (five, including non-fertilized control) $\times$ four frequencies. There was a $3.6 \mathrm{~m}$ section without a tree along the row to separate each plot of 10 trees. Therefore, each plot had a non-fertilized buffer of $3.6 \mathrm{~m}$ on all sides. Data were analyzed using SAS with two-way ANOVA in a split plot in time. Data normality and equal variances for both species passed the tests performed within the Univariate procedure in SAS. Means were separated using LS Means. Pearson's correlation coefficients ( $r$ ) were calculated to test significant associations. Values were considered statistically significant at $P<0.05$. 


\section{RESULTS}

\section{Ilex}

Mean initial height and caliper for Ilex at the start of the study (April 2005) was $1.0 \mathrm{~m}$ and 9 $\mathrm{mm}$, respectively. Interaction between rate and number of applications was not significant for height $(P=0.07)$ or height increase $(P=0.37)$. Trees responded to fertilization treatments by the end of the second growing season (October 2006) by producing taller trees at all fertilizer rates compared to the non-fertilized control (Figure 1) and taller trees at two, three, and four applications compared to a single application and control (Figure 2). Although tree height by the end of 2006 appeared to increase with number of applications, the correlation was weak $(\mathrm{r}=0.21$, $P<0.001)$. Despite the subtle effects early in the study (2006), tree height separation among treatments was less obvious by the end of the study in 2008. Final height $(4.3 \mathrm{~m} ; P=0.26)$ and height increase $(2.3 \mathrm{~m} ; P=0.35)$ was not affected by fertilizer rate or number of applications.

Caliper increase was affected by certain combinations of fertilizer rate and number of applications [i.e., there was a significant interaction between the two factors (Figure 3)]. A single application of fertilizer never resulted in a caliper response in any year compared to non-fertilized controls (cumulative data shown, Figure 3). Compared to the non-fertilized controls, more than one application resulted in greater caliper in 8

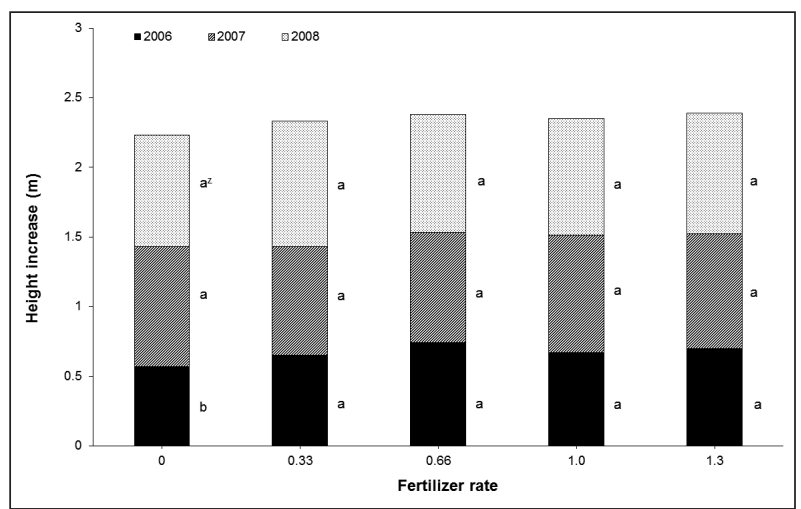

Figure 1. Ilex height increase from October 2005 through October of the indicated year with increasing fertilizer rate. Historical rate was 1.0; other rates are multiples of historical.

${ }^{z}$ For each year, mean increase among rates with different letters was statistically different at $P<0.05 ; n=16$ averaged across number of fertilizer applications because interaction was insignificant ( $P>0.05$ ); $n=4$ for zero rate (control). of 12 multiple application combinations. Neither raising (to 1.3) nor lowering (to 0.33 ) the rate of fertilizer from the historical rate (1.0) influenced trunk caliper increase for any number of applications. This suggests that the most efficient method of fertilizing this Ilex would be to divide the 0.33 rate into two applications because no other treatment enhanced caliper more.

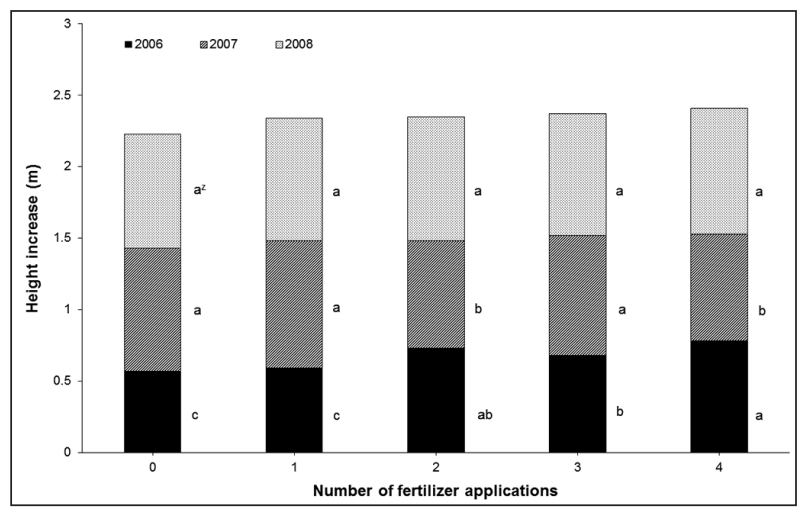

Figure 2. Ilex height increase from October 2005 through October of the indicated year with increasing number of fertilizer applications.

${ }^{2}$ For each year, mean increase among rates with different letters was statistically different at $P<0.05 ; n=16$ averaged across fertilizer rate because the interaction was insignificant $(P>0.05) ; n=4$ for zero applications (control).

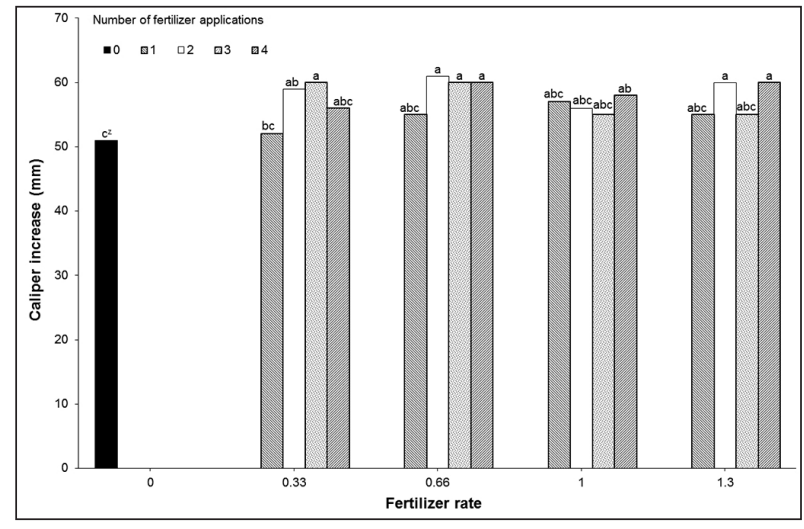

Figure 3. Interaction of fertilizer rate and number of applications on Ilex caliper increase four years after planting (2008). Historical rate was 1.0; other rates are multiples of historical.

${ }^{z}$ Means with a different letter were statistically different at $P<0.05 ; n=4$.

\section{Quercus}

Mean initial height and caliper for Quercus at the start of the study (April 2005) was $1.1 \mathrm{~m}$ and 8 $\mathrm{mm}$, respectively. Interaction between the factors rate and number of applications was not significant for height increase $(P=0.83)$. Trees respond- 
ed to all rates and number of applications by the end of the second growing season (October 2006) with fertilized trees in most treatments (except height increase at three applications), increasing in height more than non-fertilized controls (Figure 4; Figure 5). Applying more than historical 1.0 rate resulted in no height (Figure 4; $P=0.28$ ) or caliper (data not shown; $P=0.66$ ) increase by the end of the second year (2006) regardless of number of applications. Increasing the number of applications above one resulted in no height (Figure 5; $P$ $=0.09$ ) or caliper (data not shown; $P=0.12$ ) response at the end of second year (2006) for any rate.

Quercus receiving the highest three rates grew more in height in the third growing season (2007) than trees receiving the lowest rate (0.33) and the non-fertilized control; however, in the last season (2008), trees receiving all rates, including the control, had similar height increase (Figure $4 ; P=0.50$ ). Cumulative height increase at the end of the study (2008) on trees receiving fertilizer at any rate was larger than on those not fertilized, and trees at the 0.33 rate were $14 \mathrm{~cm}$ shorter $(P<0.05)$ than those receiving the 1.0 historical rate (Figure 4 ). Number of fertilizer applications had no impact on height increase in the final year $(2008 ; P=0.16)$ except for trees receiving four applications increased in height more than those receiving one application in year three (2007, Figure 5). Fertilizer rate above 0.66

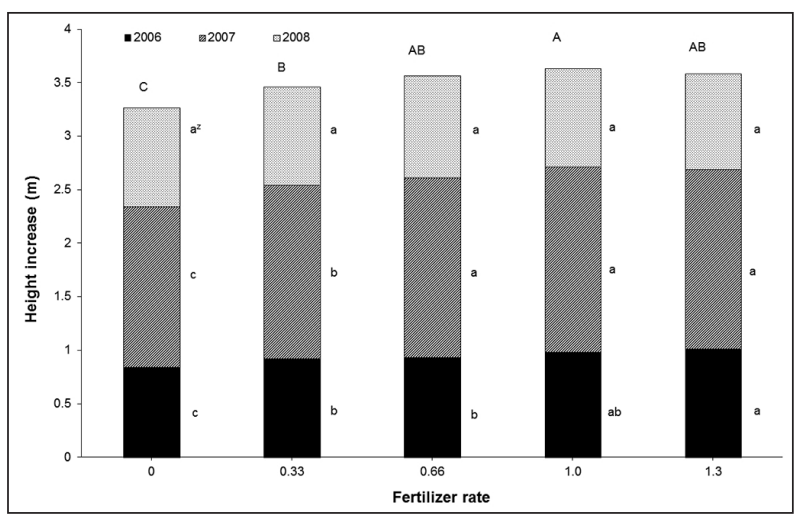

Figure 4. Quercus height increase from October 2005 through October of the indicated year with increasing fertilizer rate. Historical rate was 1.0; other rates are multiples of historical.

${ }_{z}$ For each year, mean increase among rates with different lowercase letters was statistically different at $P<0.05$; cumulative increase among rates with different uppercase letters was statistically different at $P<0.05 ; n=16$ averaged across number of fertilizer applications because interaction was insignificant; $\mathbf{n}=\mathbf{4}$ for zero rate (control). historical rate (Figure 4) or number of applications above one had no influence on height (mean of fertilized trees $=5.7 \mathrm{~m}$ ) or cumulative height increase (Figure 5) during the course of the entire study.

Although the interaction between fertilizer rate and number of applications was significant because 9 of the 16 treatment means were larger than nonfertilizer controls, caliper (mean $=91 \mathrm{~mm}$ for all fertilized trees) and caliper increase (Figure 6) were similar for all combinations of fertilized trees; the slower growth of the non-fertilized controls (caliper $=83 \mathrm{~mm}$ ) accounted for the interaction.

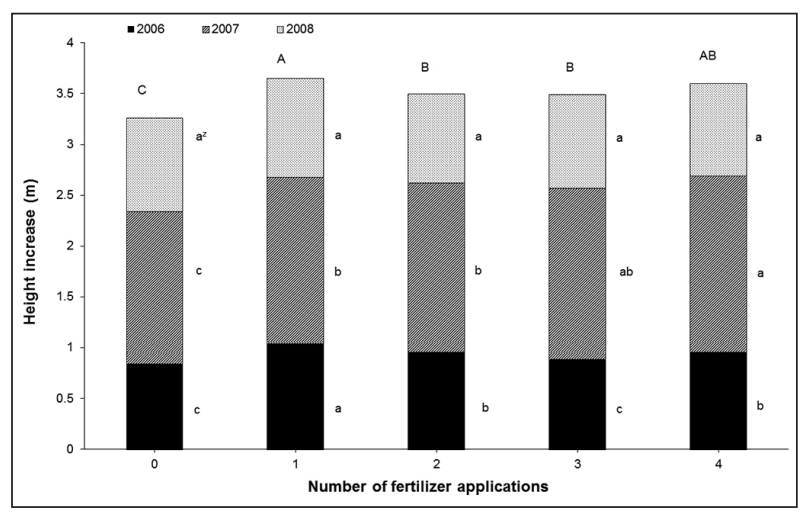

Figure 5. Quercus height increase from October 2005 through October of the indicated year with increasing number of fertilizer applications.

${ }^{2}$ For each year, mean increase among number of applications with different lowercase letters was statistically different at $P<0.05$; cumulative increase among number of applications with different uppercase letters was statistically different at $P<0.05 ; n=16$ averaged across fertilizer rate because interaction was insignificant $(P>0.05) ; n=4$ for zero applications (control).

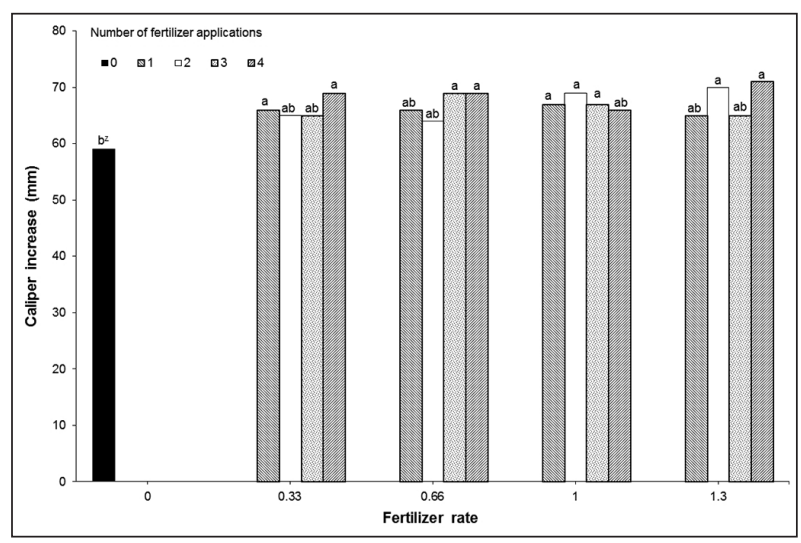

Figure 6. Effect of the interaction of fertilizer rate and number of applications on Quercus caliper increase. Historical rate was 1.0; other rates are multiples of historical.

${ }^{z}$ Means with a different letter were statistically different at $P<0.05 ; \mathrm{n}=4$. 


\section{DISCUSSION}

Caliper increase and height increase-instead of caliper and height-were used as the primary comparison metrics because this removed slight differences among trees in initial size at planting. Application of fertilizer resulted in a mean of $6 \mathrm{~mm}$ (Ilex, Figure 3) or $8 \mathrm{~mm}$ (Quercus, Figure 6) increase in caliper (mean over 40 plots in 16 fertilizer treatments) over the control during the four-year period in nursery field soil. There was little evidence to suggest that Quercus caliper increased with either number of fertilizer applications or amount of fertilizer applied (rate); one application at the low rate (0.33 historical) provided the same caliper response as the high rate (1.3 historical) divided into four applications (Figure 6). The implications on capital savings from fertilizer production, transport, application, and potential leaching into ground water are obvious. Two applications for Ilex were needed at three of the four rates (i.e., all but the 1.0 rate) in order to produce significant caliper increase compared to the non-fertilized control (Figure 3).

Height increase data generally mirrored that of caliper (i.e., fertilizing over a four-year period had no impact on Ilex height increase). Lack of differences in height increase could have been due to nursery crews shearing trees to about the same height in the plots; however, crews were given instructions to shear as they would for a typical tree of that size. The $14 \mathrm{~cm}$ increase in Quercus height at the end of the four-year period at the 1.0 historical rate $(3.64 \mathrm{~m})$ compared to the $0.33(3.50 \mathrm{~m})$ rate came at three times the fertilizer cost (Figure 4 ). The potentially lower market value for the slightly shorter (3.64 m versus $3.50 \mathrm{~m}$ $=4 \%$ ) finished crop with the same caliper could be compared with the savings from purchasing and applying one-third the amount of fertilizer to determine which is the better management alternative.

There were few consistent responses of either genus from more than one application at any fertilizer rate. One application at the 0.33 rate, which was one-third of the grower's historical rate, was enough to cause a small but significant growth response compared to the control. Increasing rate from 0.33 , or dividing the rate equally among two, three, or four applications, resulted in little or no increase in growth. In a similar study on palms (Roystonea elata Bartr.) growing in a field nursery in south Florida, reducing $\mathrm{N}$ to half the grower's historical rate had no impact on growth of any measured parameter (Migliaccio et al. 2008). Gilman and Yeager (1990) and Gilman et al. (2000) concluded that laurel oaks (Quercus laurifolia Michx.), Japanese ligustrum (Ligustrum japonicum Thunb.), southern magnolia (Magnolia grandiflora L.), and live oak (Quercus virginiana Mill.) in the same geographic region as the current study grew as well with or without fertilization. Broschat et al. (2008) suggested that not only are many tested dicots insensitive to the type of fertilizer they receive, but that under the soil and environmental conditions at many test sites, they may not benefit greatly from fertilization at all (supported by Ponder et al. 1984; Robbins 2007; Watson 2010). Extensive root systems on established woody plants (Stout 1956; Watson and Himelick 1982) probably allow for a high capacity to scavenge minerals and $\mathrm{N}$ needed for growth and development.

Rose and Joyner (2003) suggest that growth response may occur primarily in poor urban soils and not in fertile soils typical in nurseries and in university test fields, where most studies have been performed; however, they present no evidence of this. Ingram et al. (1998) suggested $28 \mathrm{~g} \mathrm{~N} / \mathrm{m}^{2}$ as adequate for many shade trees growing in Kentucky, U.S., nurseries; however, no application area was provided, making it impossible to calculate how much $\mathrm{N}$ was applied to the trees. This rate falls between the $20 \mathrm{~g} \mathrm{~N} / \mathrm{m}^{2}$ (for the first two years of production, applied to a $0.65 \mathrm{~m}^{2}$ circle around the tree) and the $40 \mathrm{~g} \mathrm{~N} / \mathrm{m}^{2}$ (for the third and fourth years) that resulted in the best growth for southern magnolia in a sandy field nursery in Florida (Gilman et al. 2000). Higher rates resulted in no more growth.

Robbins (2007) showed no tree response, compared to non-fertilized controls, to a fairly low rate of $11 \mathrm{~g} \mathrm{~N} / \mathrm{m}^{2}$ for Zelkova serrata (Thunb.) growing in an Arkansas, U.S., field nursery. Perhaps this rate was too low or the soil too fertile to provide a response in this soil type (not provided), or more likely the applied soil area $\left(0.093 \mathrm{~m}^{2}\right)$ was very small resulting in little applied $\mathrm{N}$ ( $1 \mathrm{~g} \mathrm{~N} /$ tree or approximately $0.5 \mathrm{~g} \mathrm{~N} / \mathrm{cm}$ caliper). As evidence of a relatively small amount of N, Mathers (2012) applied the same rate $\left(11 \mathrm{~g} \mathrm{~N} / \mathrm{m}^{2}\right)$, but at nine times the amount of $\mathrm{N}$ because it was applied to a larger $\left(0.84 \mathrm{~m}^{2}\right)$ area, thus explaining the resulting tree response. This suggests that rate calculated as amount of applied $\mathrm{N} /$ tree or $\mathrm{N} / \mathrm{cm}$ caliper may provide a more reliable 
comparison among various studies because tree size or the area of soil receiving fertilizer varies among studies, or one of these values was not reported.

Tested amounts of N/cm caliper $(23 \mathrm{~g} \mathrm{~N} / \mathrm{cm}$ caliper, Fini et al. 2007; $29 \mathrm{~g} \mathrm{~N} / \mathrm{cm}$ caliper, Watson 2010; up to $58 \mathrm{~g} \mathrm{~N} / \mathrm{cm}$ caliper, Struve 2002) and amounts above which there was no response $(13$ to $>26 \mathrm{~g}$ $\mathrm{N} / \mathrm{cm}$ caliper depending on $\mathrm{N}$ source, Neely et al. $1970 ; 40$ to $80 \mathrm{~g} \mathrm{~N} / \mathrm{cm}$ caliper, Perry and Hickman 1998; 4.5 to $36 \mathrm{~g} \mathrm{~N} / \mathrm{cm}$ caliper depending on tree size, Gilman et al. 2000) are within an order of magnitude of the historical rate from the current study $[$ mean $=32 \mathrm{~g} \mathrm{~N} / \mathrm{cm}$ caliper $($ range $=21$ to $41 \mathrm{~g} \mathrm{~N} / \mathrm{cm}$ caliper) across both species and all three years]. However, it would be hard to make a case for applying more than 0.33 of the historical rate based on current caliper and height data, which would amount to about 11 (32 $\mathrm{g} \times 0.33$ historical rate) $\mathrm{g} \mathrm{N} / \mathrm{cm}$ caliper/year. This falls near the bottom of the range of cited studies. Perhaps the naturally fertile soils in many nurseries combined with $\mathrm{N}$ in rainfall (Pribble and Janicki 1999) or irrigation in eastern North America, where most studies have been conducted, precluded growth responses to more than a small amount of fertilizer. Total NOx-N applied/tree $(2.4 \mathrm{mg} / \mathrm{L}$ in well water $\times 3224$ $\mathrm{L}$ irrigation/tree annually $\times$ four-year study period $=31.2 \mathrm{~g} \mathrm{~N}$ ) through irrigation during the current study was $15.3 \%$ of the total $\mathrm{N}$ applied in fertilizer at the 0.33 historical rate $(51+163+196+196 \mathrm{~g}$ $\mathrm{N}=607 \mathrm{~g} \mathrm{~N}$ fertilizer/tree for the historical rate $\div$ $0.33=202.3 \mathrm{~g} \mathrm{~N})$. Although small, this background $\mathrm{N}$ apparently supplied enough $\mathrm{N}$ to support growth that was more than $90 \%$ of that of fertilized trees. Results may have been different if the N-rich shoots pruned from trees were removed from the plots.

\section{CONCLUSIONS}

Reducing fertilizer amount to one-third of what was historically used in a shade tree field nursery, and reducing number of applications from three to either one or two, had a negligible impact on growth of one species of Ilex and Quercus. Nurseries can use the outlined approach along with $\mathrm{N}$ recovery rates from wood in harvested trees to find the most efficient strategy for applying fertilizer to their nursery crops. Managers could conduct efficiency tests similar to the one outlined here in an attempt to find the smallest amount of fertilizer required to pro- duce crops. A few selected nurseries have done this. Although the current study tested a 0.33 historical rate, the data and conversations with growers suggest that even lower rates should be included in future tests. After finding the lowest rate and smallest number of applications in a three- to four-year test, researchers recommend incorporating the most efficient rate into a couple of fields, adjusting as needed, and eventually applying the new rate to the entire operation.

\section{LITERATURE CITED}

Broschat, T.K., D.R. Sandrock, M.L. Ellliott, and E.F. Gilman. 2008. Effects of fertilizer type on quality and nutrient content of established landscape plants in Florida. HortTechnology 18:278-285.

Cabrera, R.I., and D.R. Devereaux. 1999. Crape Myrtle posttransplant growth as affected by nitrogen nutrition during nursery production. Journal of the American Society for Horticultural Science 124:4-98.

Chadwick, L.C., P.E. Tilford, and C.F. Irish. 1957. A study of some methods of fertilizing shade trees. Proceedings American Society Horticulture Science 55:519-526.

Conover, C., and J. Joiner. 1974. Influence of fertilizer source and rate on growth of woody ornamentals transplanted to stress conditions. Florida Agricultural Experiment Station Journal Series No. 5469, 7 pp. University of Florida, Gainesville.

Fini, A., F. Ferrini, P. Frangi, G. Amoroso, and F. Minoprio. 2007. Growth and physiology of field-grown Acer pseudoplatanus L. trees as influenced by irrigation and fertilization. Proceedings Southern Nurseryman Association 52:51-58.

Gilman, E.F. 1987. Response of hibiscus to soil applied nitrogen. Proceedings Florida State Horticulture Society 100:356-357.

Gilman, E.F., and T.H. Yeager. 1990. Fertilizer type and nitrogen rate affects field-grown laurel oak and Japanese ligustrum. Proceedings Florida State Horticulture Society 103:370-372.

Gilman, E.F., T.H. Yeager, and D. Kent. 2000. Fertilizer rate and type impacts magnolia and oak growth in sandy landscape soil. Journal of Arboriculture 26:177-182.

Hensley, D.L., R.E. McNeil, and R. Sundheim. 1988. Management influences growth of transplanted Magnolia grandiflora. Journal of Arboriculture 14:204-207.

Ingram, D.L., B. Roach, and M. Klahr. 1998. Effects of controlledrelease fertilizers on growth and nutrient content of field-grown nursery crops. Proceedings Southern Nurserymen Association Annual Conference 43:122-127.

Jacobs, H.L. 1930. Fertilization of shade trees. Bulletin 5, 16 pgs. The Davey Tree Expert Company, Kent, Ohio.

Khatamian, H., J.C. Pair, and R. Carrow. 1984. Effects of turf competition and fertilizer application on trunk diameter and nutrient composition of honeylocust. Journal of Arboriculture 10:156-159.

Klein, I., I. Levin, B. Bar-Yosef, R. Assaf, and A. Berkovitz. 1988. Drip nitrogen fertigation of 'Starking Delicious' apple trees. Plant and Soil 119:305-314.

Mathers, H., L. Case, and K. Daniel. 2012. Tree response to fertilizer formulation in the field. Proceedings Southern Nurserymen's Association Annual Conference 57:128-131. 
Migliaccio, K.W., B. Schaffer, Y.C. Li, E. Evans, J.H. Crane, and R. Munoz-Carpena. 2008. Assessing benefits of irrigation and nutrient management practices on a southeastern Florida royal palm (Roystonea elata) field nursery. Irrigation Science 27:57-66.

Neely, D., E.B. Himelick, and W.R. Crowley, Jr. 1970. Fertilization of established trees: A report of field studies. Illinois Natural History Survey Bulletin, Volume 30, article 4.

Perry, E., and G.W. Hickman. 1998. Correlating foliar nitrogen levels with growth in two landscape tree species. Journal of Arboriculture 24:149-153.

Ponder, H.G., C.H. Gilliam, E. Wilkinson, J. Eason, and C.E. Evans. 1984. Influence of trickle irrigation and nitrogen rates on Acer rubrum L. Journal of Environmental Horticulture 2:40-43.

Pribble, J.R., and A.J. Janicki. 1999. Atmospheric deposition contributions to nitrogen and phosphorus loadings in Tampa Bay: Intensive wet and dry deposition data collection and analysis. Final Report prepared for Tampa Bay Estuary Program, St. Petersburg, Florida.

Robbins, J.A. 2006. Effect of nitrogen on the growth of field-grown ornamental trees in eastern Arkansas. Proceedings Southern Nurseryman Association Research Conference 51:113-117.

Robbins, J.A. 2007. Effect of nitrogen source on trunk caliper growth of field-grown zelkova. Proceedings Southern Nurseryman Association Research Conference 52:68-69.

Rose, M.A. 1999. Nutrient use patterns in woody perennials: Implications for increasing fertilizer efficiency in field-grown and landscape ornamentals. HortTechnology. 9: 613-617.

Rose, M.A., and B. Joyner. 2003. Tree and Shrub Fertilization. pp. 121-126. In: A. Siewert, B. Rao, and D. Marion (Eds.). Proc. from an International Conference on Tree and Shrub Fertilization, TruGreen Chemlawn Research on Fertilization of Woody Ornamentals. International Society of Arboriculture, Champaign, IL.

Schulte, J.R., and C.E. Whitcomb. 1975. Effects of soil amendments and fertilizer levels on the establishment of silver maple. Journal of Arboriculture 1:192-195.

Shoup, S., R. Reavis, and C.E. Whitcomb. 1981. Effects of pruning and fertilization on establishment of bareroot deciduous trees. Journal of Arboriculture 7:155-157.

Stout, B.B. 1956. Studies of root systems of deciduous trees. Black Forest Bulletin 15:1-45.

Struve, D.K. 2002. A review of shade tree nitrogen fertilization research in the United States. Journal of Arboriculture 28:252-263.

van de Werken, H. 1981. Fertilization and other factors enhancing the growth of young shade trees. Journal of Arboriculture 7:33-37.

van de Werken, H. 1984. Fertilization practices as they influence the growth rate of young shade trees. Journal of Environmental Horticulture 2:64-69.

Warren, S. 1993. Growth and nutrient concentration in flowering dogwood after nitrogen fertilization and dormant root pruning. Journal of Arboriculture 19:57-63.

Watson, G. 2010. The effect of broadcast nitrogen fertilization rates and placement on the growth of green ash trees. Arboriculture \& Urban Forestry 36:179-182.

Watson, G.W. 1994. Root growth response to fertilizers. Journal of Arboriculture 20:4-8.

Watson, G.W., and E.B. Himelick. 1982. Root distribution of nursery trees and its relation to transplant success. Journal of Arboriculture 8:225-229.
Whitcomb, C.E. 1981. Response of woody plants to bermudagrass competition and fertility. Journal of Arboriculture 7:191-194.

Wright, R.D., and E. B. Hale. 1983. Growth of three shade tree genera as influenced by irrigation and nitrogen rates. Journal of Environmental Horticulture 1:5-6.

\section{Edward F. Gilman (corresponding author) \\ Professor \\ University of Florida \\ Gainesville, Florida, U.S.}

Michael D. Marshall

Vice President

Marshall Tree Farm

Morriston, Florida, U.S.

Zusammenfassung. Die Düngeempfehlungen für die Produktion von Schattenbäumen in den Baumschulfeldern Nordamerikas scheinen auf Tradition und Baumleistung zu basieren. Es gibt wenig empirische Daten. Diese Studie wurde entwickelt, um die Effizienz von reduzierten traditionellen oder historischen Düngeempfehlungen und Anzahl der Applikationen für zwei Arten zu untersuchen und um ein Protokoll für Produzenten zu präsentieren, um die Düngeleistung zu testen. Eine traditionelle Düngergabe wurde zusammen mit 4 anderen appliziert: Null, 1/3, 2/3 oder 1 $1 / 3$ der traditionellen Gabe. Der Dünger wurde in eine, zwei, drei (trad.) oder vier Gaben während der Vegetationsperiode aufgeteilt. Die Studie wurde auf einem feinen Sandboden mit 680 Bäumen aus jeder Art in benachbarten Reihen im gleichen Feld. Es gab $16 \mathrm{Be}-$ handlungskombinationen und eine nicht gedüngte Kontrolle. Eine auf 1/3 der historischen Werte reduzierte Düngergabe und eine Reduktion der Gaben von drei auf zwei oder eine führte zu wenig wenn überhaupt messbarer Reduktion des Stammdurchmessers oder Höhenwachstum in der vierjährigen Periode. Diese Arten schienen unabhängig von der zusätzlichen Stickstoffgabe zu wachsen. Produzenten können sich mit einem Forscherteam zusammenschließen, um effiziente Düngergaben und Anzahl der Applikationen, die die Produktionskosten vermindern, suchen.

Resumen. Las recomendaciones de fertilización para la producción de árboles de sombra en vivero en América del Norte se basan en la tradición y el comportamiento de los árboles, hay pocos datos empíricos. Este estudio fue diseñado para examinar la eficacia de la reducción de la cantidad tradicional o histórica de fertilizantes (tasa) y el número de aplicaciones para dos taxa y para presentar un protocolo para los cultivadores y poner a prueba la eficiencia del uso de fertilizantes. Se aplicó la tasa tradicional de fertilizante junto con otras cuatro: cero, un tercio, dos tercios, o de uno y un tercio del tradicional. El fertilizante fue dividido en una, dos, tres (tradicional), o cuatro partes iguales aplicadas durante la temporada de crecimiento. El estudio se realizó en un suelo fino arenoso del campo con 680 árboles de cada taxa en parcelas adyacentes. Hubo 16 combinaciones de tratamientos factoriales además de un control no fertilizado. La tasa de fertilizantes cortada a un tercio de la tasa histórica y el número de aplicaciones reducido de tres a uno o dos dio como resultado poca o ninguna reducción en el diámetro del tronco o el crecimiento en altura durante el período de cuatro años. Estos taxones parecían crecer casi independientemente de la estrategia de aplicación de nitrógeno. Los productores pueden asociarse con un equipo de investigación para encontrar una tasa eficiente de fertilizantes y el número de aplicaciones que podrían reducir los costos de producción. 